University of Nebraska - Lincoln DigitalCommons@University of Nebraska - Lincoln

$1-2002$

EFFECTS OF MANAGEMENT PRACTICES

ON GRASSLAND BIRDS: HENSLOW'S SPARROW

James R. Herkert

Follow this and additional works at: http:// digitalcommons.unl.edu/empgb

Part of the Ornithology Commons, Plant Sciences Commons, and the Terrestrial and Aquatic Ecology Commons

This Article is brought to you for free and open access by the US Geological Survey at DigitalCommons@University of Nebraska - Lincoln. It has been accepted for inclusion in Effects of Management Practices on Grassland Birds by an authorized administrator of DigitalCommons@University of Nebraska - Lincoln. 


\section{EFFECTS OF MANAGEMENT PRACTICES ON GRASSLAND BIRDS: \\ HENSLOW'S SPARROW}

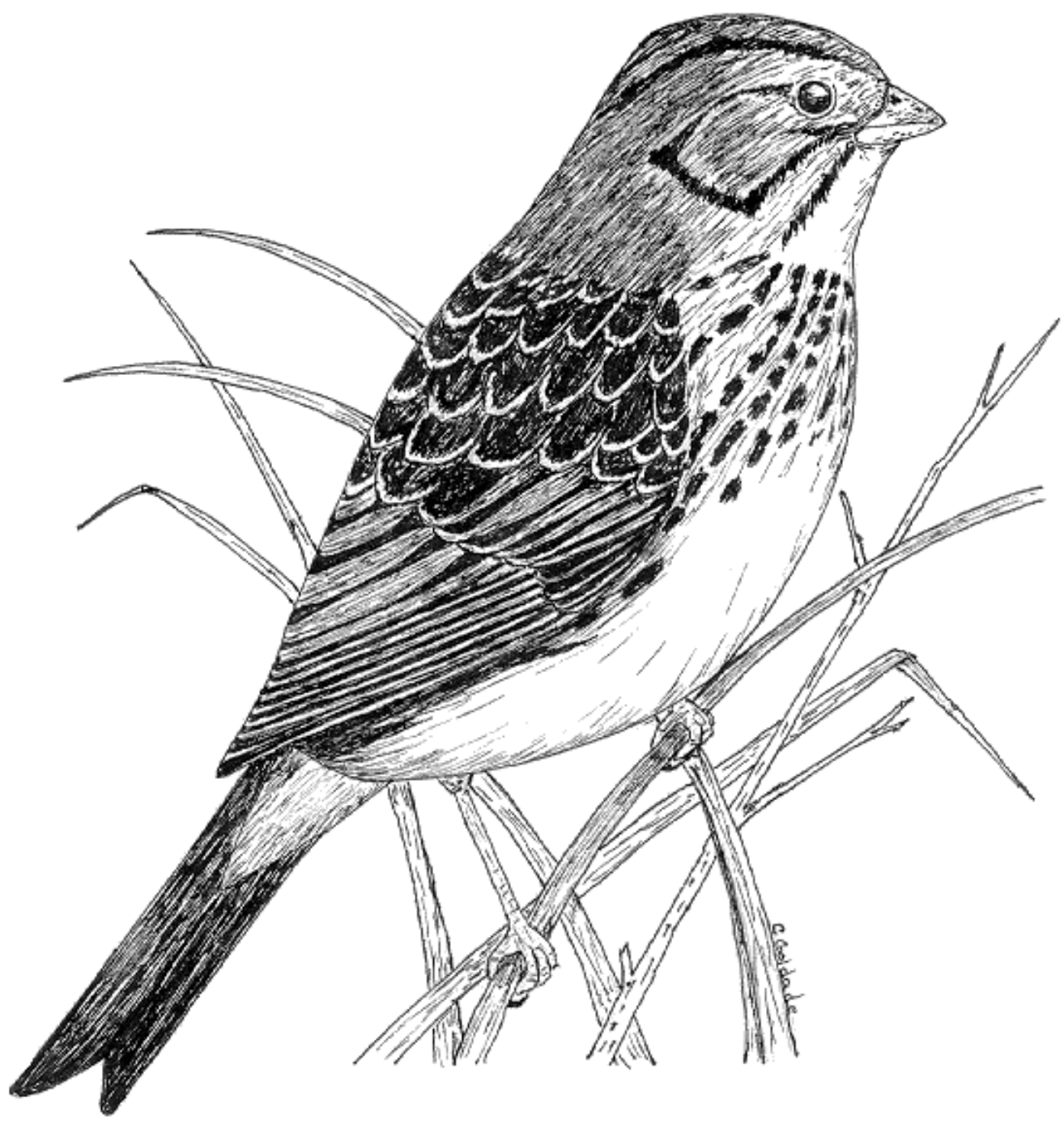

Grasslands Ecosystem Initiative

Northern Prairie Wildlife Research Center

U.S. Geological Survey

Jamestown, North Dakota 58401 
This report is one in a series of literature syntheses on North American grassland birds. The need for these reports was identified by the Prairie Pothole Joint Venture (PPJV), a part of the North American Waterfowl Management Plan. The PPJV recently adopted a new goal, to stabilize or increase populations of declining grassland- and wetland-associated wildlife species in the Prairie Pothole Region. To further that objective, it is essential to understand the habitat needs of birds other than waterfowl, and how management practices affect their habitats. The focus of these reports is on management of breeding habitat, particularly in the northern Great Plains.

Suggested citation:

Herkert, J. R. 1998 (revised 2002). Effects of management practices on grassland birds: Henslow’s Sparrow. Northern Prairie Wildlife Research Center, Jamestown, ND. 17 pages.

Species for which syntheses are available or are in preparation:

$\begin{array}{ll}\text { American Bittern } & \text { Grasshopper Sparrow } \\ \text { Mountain Plover } & \text { Baird's Sparrow } \\ \text { Marbled Godwit } & \text { Henslow’s Sparrow } \\ \text { Long-billed Curlew } & \text { Le Conte's Sparrow } \\ \text { Willet } & \text { Nelson's Sharp-tailed Sparrow } \\ \text { Wilson's Phalarope } & \text { Vesper Sparrow } \\ \text { Upland Sandpiper } & \text { Savannah Sparrow } \\ \text { Greater Prairie-Chicken } & \text { Lark Sparrow } \\ \text { Lesser Prairie-Chicken } & \text { Field Sparrow } \\ \text { Northern Harrier } & \text { Clay-colored Sparrow } \\ \text { Swainson's Hawk } & \text { Chestnut-collared Longspur } \\ \text { Ferruginous Hawk } & \text { McCown's Longspur } \\ \text { Short-eared Owl } & \text { Dickcissel } \\ \text { Burrowing Owl } & \text { Lark Bunting } \\ \text { Horned Lark } & \text { Bobolink } \\ \text { Sedge Wren } & \text { Eastern Meadowlark } \\ \text { Loggerhead Shrike } & \text { Western Meadowlark } \\ \text { Sprague’s Pipit } & \text { Brown-headed Cowbird }\end{array}$




\title{
EFFECTS OF MANAGEMENT PRACTICES ON GRASSLAND BIRDS:
}

\section{HENSLOW'S SPARROW}

\author{
James R. Herkert
}

Series Coordinator: Douglas H. Johnson

Series Assistant Coordinator: Lawrence D. Igl

\begin{abstract}
Reviewers: Lori B. Pruitt and Maiken Winter
\end{abstract}
Range Map: Jeff T. Price

Cover Art: Christopher M. Goldade

Major Funding: Prairie Pothole Joint Venture, U.S. Fish and Wildlife Service U.S. Geological Survey

Funding also provided by: U.S. Forest Service

\section{Collaborators:}

Louis B. Best, Iowa State University

Carl E. Bock, University of Colorado

Brenda C. Dale, Canadian Wildlife Service

Stephen K. Davis, Saskatchewan Wetland Conservation Corporation James J. Dinsmore, Iowa State University

James K. Herkert, Illinois Endangered Species Protection Board

Fritz L. Knopf, Midcontinent Ecological Science Center

Rolf R. Koford, Iowa Cooperative Fish and Wildlife Research Unit

David R. C. Prescott, Alberta NAWMP Centre

Mark R. Ryan, University of Missouri

David W. Sample, Wisconsin Department of Natural Resources

David A. Swanson, Ohio Division of Wildlife

Peter D. Vickery, Massachusetts Audubon Society

John L. Zimmerman (retired), Kansas State University

May 1998

(revised January 2002) 


\section{ORGANIZATION AND FEATURES OF THIS SPECIES ACCOUNT}

Information on the habitat requirements and effects of habitat management on grassland birds were summarized from information in more than 4,000 published and unpublished papers. A range map is provided to indicate the relative densities of the species in North America, based on Breeding Bird Survey (BBS) data. Although birds frequently are observed outside the breeding range indicated, the maps are intended to show areas where managers might concentrate their attention. It may be ineffectual to manage habitat at a site for a species that rarely occurs in an area. The species account begins with a brief capsule statement, which provides the fundamental components or keys to management for the species. A section on breeding range outlines the current breeding distribution of the species in North America, including areas that could not be mapped using BBS data. The suitable habitat section describes the breeding habitat and occasionally microhabitat characteristics of the species, especially those habitats that occur in the Great Plains. Details on habitat and microhabitat requirements often provide clues to how a species will respond to a particular management practice. A table near the end of the account complements the section on suitable habitat, and lists the specific habitat characteristics for the species by individual studies. A special section on prey habitat is included for those predatory species that have more specific prey requirements. The area requirements section provides details on territory and home range sizes, minimum area requirements, and the effects of patch size, edges, and other landscape and habitat features on abundance and productivity. It may be futile to manage a small block of suitable habitat for a species that has minimum area requirements that are larger than the area being managed. The Brown-headed Cowbird (Molothrus ater) is an obligate brood parasite of many grassland birds. The section on cowbird brood parasitism summarizes rates of cowbird parasitism, host responses to parasitism, and factors that influence parasitism, such as nest concealment and host density. The impact of management depends, in part, upon a species' nesting phenology and biology. The section on breeding-season phenology and site fidelity includes details on spring arrival and fall departure for migratory populations in the Great Plains, peak breeding periods, the tendency to renest after nest failure or success, and the propensity to return to a previous breeding site. The duration and timing of breeding varies among regions and years. Species' response to management summarizes the current knowledge and major findings in the literature on the effects of different management practices on the species. The section on management recommendations complements the previous section and summarizes specific recommendations for habitat management provided in the literature. If management recommendations differ in different portions of the species' breeding range, recommendations are given separately by region. The literature cited contains references to published and unpublished literature on the management effects and habitat requirements of the species. This section is not meant to be a complete bibliography; a searchable, annotated bibliography of published and unpublished papers dealing with habitat needs of grassland birds and their responses to habitat management is posted at the Web site mentioned below.

This report has been downloaded from the Northern Prairie Wildlife Research Center WorldWide Web site, www.npwrc.usgs.gov/resource/literatr/grasbird/grasbird.htm. Please direct comments and suggestions to Douglas H. Johnson, Northern Prairie Wildlife Research Center, U.S. Geological Survey, 8711 37th Street SE, Jamestown, North Dakota 58401; telephone: 701253-5539; fax: 701-253-5553; e-mail: Douglas_H_Johnson@usgs.gov. 


\section{HENSLOW'S SPARROW}

(Ammodramus henslowii)

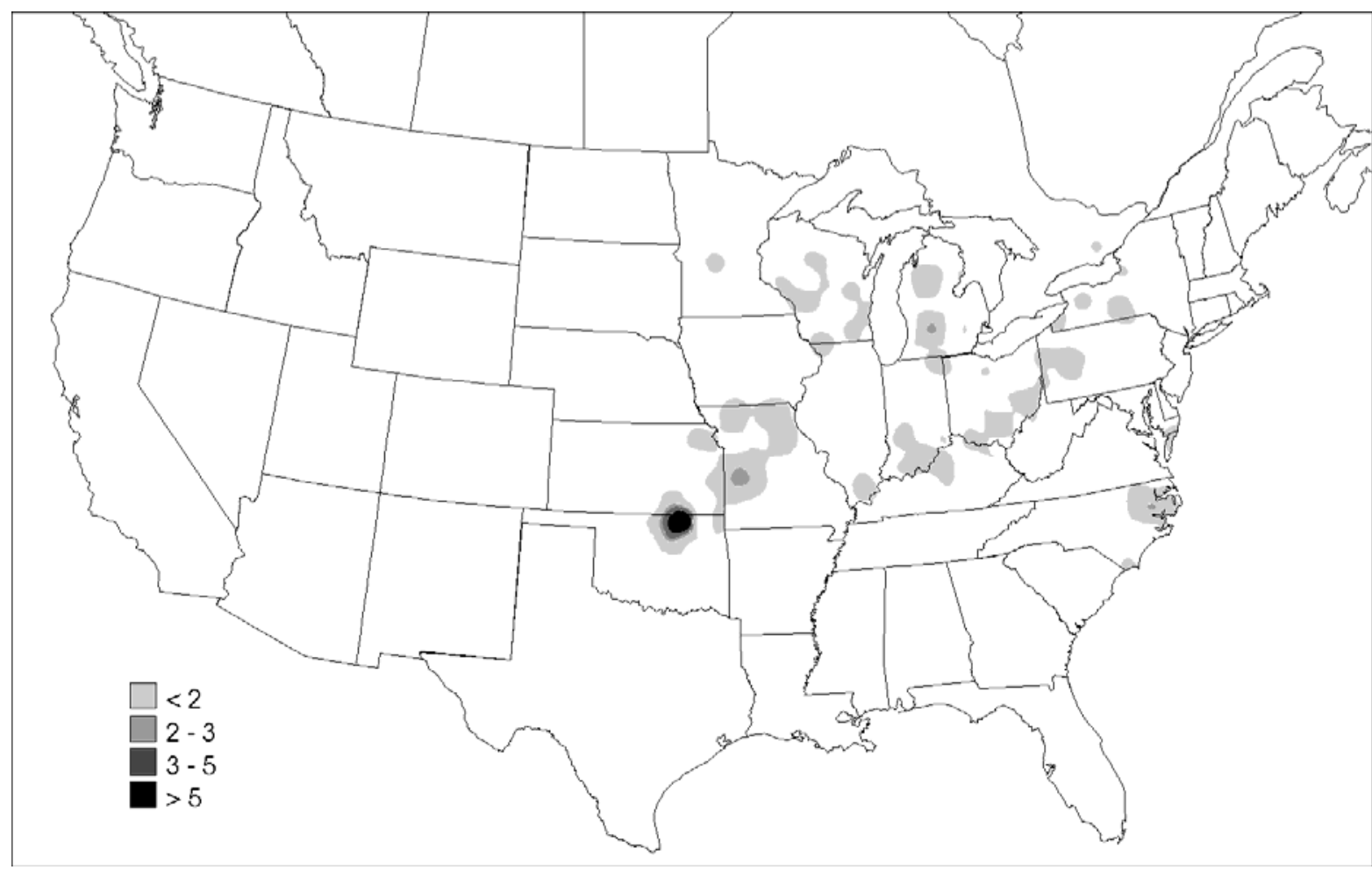

Figure. Breeding distribution of Henslow's Sparrow in the United States and southern Canada, based on Breeding Bird Survey data, 1985-1996. Scale represents average number of individuals detected per route per year. Map from J. T. Price, American Bird Conservancy, Boulder, Colorado, pers. comm.

Keys to management are providing large areas with suitable habitat (tall, dense, herbaceous vegetation with well-developed litter), avoiding habitat disturbances during the breeding season, and controlling succession.

\section{Breeding range:}

Henslow's Sparrows breed from southern Minnesota through Wisconsin and Michigan to southern Ontario, south to northeastern Oklahoma, Illinois, and Kentucky, and east to eastern North Carolina and New Hampshire (National Geographic Society 1987). (See figure for the relative densities of Henslow's Sparrows in the United States and southern Canada, based on Breeding Bird Survey data.)

\section{Suitable habitat:}

Henslow's Sparrows use grasslands that have well-developed litter (Wiens 1969, Robins 1971, Rotenberry and Wiens 1980, Kahl et al. 1985, Hanson 1994, Bollinger 1995, Mazur 1996, Michaels 1997, Winter 1999, Cully and Michaels 2000), relatively high cover of standing dead residual vegetation (Zimmerman 1988, Sample 1989, Zimmerman 1988, Mazur 1996, Melde and Koford 1996), tall, dense vegetation (Robins 1971; Skinner 1974; Skinner et al. 1984; Clawson 1991; Herkert 1991, 1994a), and generally low woody stem densities (Kahl et al. 1985, Hands et al. 1989, Sample 1989, Herkert 1994a, Mazur 1996, Winter 1998). Henslow’s Sparrow habitat 
also is characterized by a high percentage of grass cover and scattered forbs for song perches (Wiens 1969, Robins 1971, Skinner et al. 1984, Herkert 1994b, Winter 1998). Studies in Wisconsin and Illinois have found no apparent preference for native, warm-season vs. tame, cool-season grasses (Sample 1989, Herkert 1994a). However, Birkenholz (1973) found this species to be most common in native grasses and to avoid a nearby field of Kentucky bluegrass (Poa pratensis) at one site in Illinois. In Missouri, Henslow's Sparrows were not present in either tame or native hayfields (Skinner 1975). Henslow's Sparrows may use idle hayfields, Conservation Reserve Program lands, or wet meadows (Hands et al. 1989, Helzer 1996, Koford 1997, Helzer and Jelinski 1999).

Studies have been inconclusive regarding the amount of woody vegetation that will be tolerated by Henslow's Sparrows, although it is generally accepted that encroachment by woody vegetation eventually precludes use by this species (Piehler 1987, Smith 1992, Melde and Koford 1996, Pruitt 1996). Several studies have indicated that Henslow's Sparrows prefer areas with low density of woody vegetation (Peterson 1983; Kahl et al. 1985; Zimmerman 1988; Mazur 1996; Michaels 1997; Winter 1998, 1999; Cully and Michaels 2000). Densities of tall $(>2 \mathrm{~m})$ shrubs/trees were $70 \%$ higher at unoccupied areas than at occupied areas at one site in northeastern Illinois (Herkert and Glass 1999). However, a different Illinois study found no significant difference in woody stem densities for shrubs $<2 \mathrm{~m}$ tall (Herkert 1994a), and a Minnesota study found no significant difference in the number of trees, shrubs, and bushes between areas used and not used by Henslow’s Sparrows (Hanson 1994). In Wisconsin, a positive correlation was detected between Henslow's Sparrow abundance and woody cover $<1$ $\mathrm{m}$; however, despite this positive correlation, percent woody cover $<1 \mathrm{~m}$ at occupied sites was low $(0.79 \%)$, as was total woody cover $(1.69 \%)$ (Sample 1989$)$. A table near the end of the account lists the specific habitat characteristics for Henslow's Sparrows by study.

\section{Area requirements:}

Although individual territories are small (0.18-1.0 ha) (Wiens 1969, Robins 1971, Piehler 1987, O’Leary and Nyberg 2000), field size has been identified as an important component of Henslow's Sparrow habitat (Bollinger 1991, 1995; Smith and Smith 1992; Herkert 1994a,b; Mazur 1996; Swengel 1996). Henslow’s Sparrows are more likely to be encountered, and densities may be higher, in large grassland areas than in small areas (Herkert 1994a,b; Bollinger 1995; Mazur 1996; Swengel 1996; Winter 1996, 1998; Winter and Faaborg 1999), and large grasslands may be needed to support persistent populations (Pruitt 1996). Area was found to be the best predictor of Henslow's Sparrow occurrence in grasslands in Illinois and New York (Herkert 1994a,b; Bollinger 1995). In Kansas and New York, Henslow’s Sparrow were observed in areas with $\geq 30$ ha of contiguous grassland (Zimmerman 1988, Smith and Smith 1992, Mazur 1996); in Illinois, the estimated area required for Henslow's Sparrows to be detected $50 \%$ of the time was $\geq 55$ ha (Herkert 1994b). Although Henslow's Sparrows are more common in large fields and occupy them first in spring (Mazur 1996), Henslow's Sparrows also show evidence of nesting activity in small ( $<50 \mathrm{ha}$ ) grasslands (Robins 1971; Hanson 1994; Mazur 1996; Winter 1996, 1998). No studies have investigated the relationship between patch size and the rate of brood parasitism by Brown-headed Cowbirds (Molothrus ater) on Henslow's Sparrows.

Grassland isolation also may influence the distribution of Henslow’s Sparrows (Winter 1998). In Missouri, Henslow's Sparrows were absent from a 28-ha isolated prairie fragment, but were present in a 16-ha fragment that was $1.6 \mathrm{~km}$ from a larger prairie where Henslow's 
Sparrows were present (Hayden 1985). In Missouri tallgrass prairie fragments, density of Henslow's Sparrows increased with the total area of grassland in the surrounding landscape and with decreasing distance among grassland patches (Winter 1998). Although Henslow's Sparrows are sensitive to habitat fragmentation, nesting success does not seem to be influenced by fragment size (Winter 1998, 1999; Winter et al. 2000). In Missouri tallgrass prairie fragments, nest success was lower $<50 \mathrm{~m}$ from a shrubby edge, presumably because of increased mammalian activity and increased mammalian depredation of nests near edges (Winter 1998, Winter et al. 2000). In Illinois, Henslow's Sparrows were more inclined to hold territories in the interior of fields than in the $50 \mathrm{~m}$ between the interior of the field and the wooded boundary (O’Leary and Nyberg 2000).

Brown-headed Cowbird brood parasitism:

Although Friedmann and Kiff (1985) suggested that Henslow’s Sparrows may be a frequent host in some locations, only three known rates of brood parasitism by Brown-headed Cowbirds have been reported. In Missouri, Winter (1999) reported that 5\% of 59 nests were parasitized. In Oklahoma, 8\% of 24 nests were parasitized (Reinking et al. 2000). In Ontario, 8\% of 12 nests were parasitized (Peck and James 1987).

Breeding-season phenology and site fidelity:

Henslow's Sparrows arrive on their breeding grounds from late March to late April, and nest from May to mid-August, although nests with young have been found as late as September (Graber 1968, Robins 1971, Michaels 1997, Winter 1998). In southwestern Missouri, two nest initiation peaks occurred in late May and in mid-June (Winter 1999). In Maryland, five banded adult males exhibited site fidelity by returning to a prior year's breeding area (Skipper 1998). Fall migration begins in September, and most birds have vacated the breeding grounds by late October (Graber 1968, Robins 1971).

Henslow's Sparrows apparently will renest after a first nest fails, and nests found with eggs in mid-August or dependent young in September suggest that the species may be doublebrooded (Graber 1968). In southwestern Missouri, Winter (1998) found that Henslow’s Sparrows were double-brooded. In southern Michigan, Henslow’s Sparrows commonly raised two broods per nesting season (Robins 1971), whereas, in Wisconsin, second broods were uncommon (Wiens 1969). In Maryland, fledglings were found in late July, which suggested that double-broodedness had occurred (Skipper 1998).

Species’ response to management:

Periodic disturbance may be necessary to maintain suitable habitat for Henslow's Sparrows, although disturbance reduces habitat available to Henslow's Sparrows for one or two breeding seasons (Zimmerman 1988, Herkert 1994a, Melde and Koford 1996). Henslow's Sparrows generally avoid areas that have been recently disturbed by burning, mowing, or grazing because of the removal of standing dead vegetation (Eddleman 1974, Skinner et al. 1984, Zimmerman 1988, Volkert 1992, Herkert 1994a). Henslow's Sparrows are generally absent from areas during the first growing season following prescribed fire (Eddleman 1974, Hayden 1985, Zimmerman 1988, Clawson 1991, Schulenberg et al. 1993, Herkert 1994a). In Kansas, Henslow's Sparrows were absent on annually burned tallgrass prairie (Zimmerman 1997), and were present on areas 2-3 growing seasons postfire significantly more than areas $0-1$ and $>4$ growing seasons postfire (Michaels 1997). In Wisconsin, Henslow’s Sparrows were most 
abundant on a restored tallgrass prairie 2-3 yr postfire (Volkert 1992). After half of the prairie was burned a second time, Henslow's Sparrows occupied only the unburned half. In Oklahoma and Kansas, Henslow's Sparrows avoided nesting in spring-burned tallgrass prairie (Reinking and Hendricks 1993, Schulenberg et al. 1993). In Illinois, densities were usually 20-50\% lower in areas during the second growing season postfire than they were in areas three or more growing seasons postfire (Herkert 1994a, Herkert and Glass 1999). No differences were found among densities 3-5 growing seasons postfire (Herkert and Glass 1999). In Missouri tallgrass prairies, Henslow's Sparrow densities were reduced in the first growing season postfire, but no difference in densities was found 2-4 growing seasons postfire (Swengel 1996, Winter 1998). However, Henslow's Sparrows have been found breeding on areas in Missouri that were burned the same spring (Winter 1998, 1999). Nests in areas burned the same spring were placed close to the ground within large clumps of grass.

In Illinois, mowing tended to reduce but not eliminate Henslow's Sparrows in the growing season immediately following mowing (Herkert 1994a). However, timing of mowing the previous year may influence whether or not Henslow's Sparrow occupy a particular field. In New York, fields mowed late the previous year were avoided at the beginning of the breeding season, but some were occupied later in the season once vegetation has recovered (Mazur 1996). However, in an earlier New York study, Henslow's Sparrows bred in pastures that had been mowed in late July to August 1-6 yr earlier (Smith and Smith 1992). Henslow's Sparrows continue nesting late (i.e., August) into the summer (Potter 1915, Reinking and Hendricks 1983) and abandon fields once they are mowed (George 1952, Graber 1968, Hayden 1985). Many nests and fledglings are destroyed by mowing during the breeding season (M. Winter, University of Missouri, Columbia, Missouri, pers. comm.). Therefore mowing should not be allowed in areas with nesting Henslow's Sparrows until after the breeding season (about 15 August). Even though late-season (early August) mowing can destroy Henslow's Sparrows nests (Potter 1915), conservation mowing in Missouri (one annual cut occurring after mid-July) was found to result in higher densities of Henslow's Sparrows than in burned areas (Swengel 1996). In Missouri tallgrass prairie fragments, Henslow's Sparrow densities were lower in areas hayed the previous year than those hayed two years earlier (Winter 1998).

Grazing also influences Henslow's Sparrows distribution and abundance. In general, moderately to heavily grazed areas are not used by Henslow's Sparrows (Peterson 1983; Skinner et al. 1984; Zimmerman 1988; J. R. Herkert, Illinois Endangered Species Protection Board, Springfield, Illinois, unpublished data). At Konza Prairie in Kansas, Henslow's Sparrows were not encountered until grazing had been halted for 2 yr (Zimmerman and Finck 1982). However, Henslow's Sparrows have been reported to occupy areas that are lightly grazed (Skinner et al. 1984, Swengel 1996). In Missouri, Henslow’s Sparrow densities were highest on lightly grazed (vegetation height $>30.4 \mathrm{~cm}$ ) pastures, followed by idle pastures; they were not found on heavily grazed (vegetation height $\leq 10.2 \mathrm{~cm}$ ) pastures (Skinner 1975). In New York, Henslow's Sparrows were found on lightly grazed pastures occupied annually by cattle from 15 May to 15 October. These pastures also had been mowed in late July to August in the previous year (Smith and Smith 1992). In southwestern Wisconsin, Henslow's Sparrows were nearly equally abundant in rotationally grazed pastures, continuously grazed pastures, and ungrazed pastures (Temple et al. 1999). Ungrazed grasslands were neither mowed or grazed from 15 May to 1 July. Continuously grazed sites were grazed throughout the summer at levels of 2.5- 4 animals/ha. Rotationally grazed pastures, stocked with 40-60 animals/ha, were grazed for 1-2 d 
and then left undisturbed for 10-15 d before being grazed again; pastures averaged 5 ha. All sites were composed of 50-75\% cool-season grasses, 7-27\% legumes, and 8-23\% forbs.

Henslow's Sparrow populations tend to increase through the summer (Mazur 1996, J. R. Herkert, Illinois Endangered Species Protection Board, Springfield, Illinois, pers. obs.) and latearriving (after 31 May) birds may use areas typically avoided by early-arriving birds, such as burned or mowed areas (Skinner et al. 1984; Mazur 1996; M. Winter, pers. comm.).

\section{Management Recommendations:}

Where possible, provide $\geq 30$ ha of contiguous grassland (Zimmerman 1988, Smith and Smith 1992, Mazur 1996). If contiguous management units are not available, provide a complex of smaller units located near enough to one another to facilitate colonization from adjacent territories in available habitat (Mazur 1996). Create large, grassy areas near small prairie fragments; small prairie fragments can support higher densities of Henslow's Sparrows if surrounded by other grassland habitat (Winter 1998). Remove woody vegetation within and along the periphery of grassland fragments to discourage predators that may use woody vegetation as travel corridors and to enlarge the amount of interior grassland (Winter 1998, O’Leary and Nyberg 2000).

Never burn, mow, or otherwise disturb an entire area in one breeding season because disturbance reduces available habitat for one or two growing seasons (Herkert et al. 1993, Hanson 1994, Melde and Koford 1996). Implement a rotational disturbance regime to maintain grassland habitat (Zimmerman 1988, Herkert 1994a, Melde and Koford 1996).

In order to avoid destruction of nests, conduct management treatments before birds arrive in the spring (15 April) or after the young have fledged (15 September) (Smith 1992, Hanson 1994, Mazur 1996).

Provide dense and moderately tall (>30 cm) grassy vegetation (Smith 1992).

Removal of woody vegetation is needed when it becomes taller than the fully grown herbaceous vegetation (Smith 1992, Herkert et al. 1993, Mazur 1996).

Prevent encroachment of woody vegetation with periodic prescribed fire (Eddleman 1974). In Kansas, use a rotational burning program in which 3-4 adjacent tracts of prairie are burned on a 3-4 yr cycle; incidental observations suggest that each patch should be 30 ha (Zimmerman 1988). In Missouri, use a rotational burning program in which $20-30 \%$ of the site is burned each year (Winter 1998). Management units should be at least 20-30 ha, if possible (Herkert 1994a). In Missouri tallgrass prairie, annually burn one-third to one-half of a management area to maintain suitable habitat (Clawson 1991). Burning is preferred over haying, because vegetation recovers more quickly after burning than haying (Winter 1998).

Prescribed burns should be conducted in early spring (March to early April) or late fall (October and November) (Herkert et al. 1993). 
In New York, burn once every 5-6 yr or mow every 4-5 yr (Mazur 1996). These intervals will allow vegetation to recover between disturbances to provide suitable habitat while keeping succession in check.

In Missouri, implement conservation haying (one annual cut after mid-July) on a 2-3 yr rotation (Swengel 1996).

In Missouri, provide idle or lightly grazed grasslands. Light grazing was defined as grazing pressure that left $>40 \%$ vegetative cover at $25 \mathrm{~cm}$ (Skinner 1982, Skinner et al. 1984).

Grassland restoration areas should be $\geq 50$ ha and preferably $>100$ ha in size (Herkert et al. 1993). 
Table. Henslow's Sparrow habitat characteristics.

\begin{tabular}{|c|c|c|c|}
\hline Author(s) & Location(s) & Habitat(s) Studied* & Species-specific Habitat Characteristics \\
\hline Birkenholz 1973 & Illinois & $\begin{array}{l}\text { Idle, idle tallgrass, idle } \\
\text { tame, wetland, wet } \\
\text { meadow }\end{array}$ & $\begin{array}{l}\text { Were most abundant in meadows of bluejoint } \\
\text { (Calamagrostis canadensis), little bluestem } \\
\text { (Schizachyrium scoparium), and prairie dropseed } \\
\text { (Sporobolous heterolepis) with dense grass cover }<60 \mathrm{~cm} \\
\text { tall; were not found in areas dominated by tall grasses or } \\
\text { shrubs }\end{array}$ \\
\hline Bollinger 1995 & New York & Tame hayland & $\begin{array}{l}\text { Abundance was positively associated with field size and } \\
\text { negatively associated with vegetation height }\end{array}$ \\
\hline Eddleman 1974 & Kansas & $\begin{array}{l}\text { Burned tallgrass, } \\
\text { burned tallgrass } \\
\text { pasture, idle tallgrass, } \\
\text { tallgrass pasture, wet } \\
\text { meadow }\end{array}$ & $\begin{array}{l}\text { Used unburned or ungrazed areas in moderately dense } \\
\text { vegetation } 0.6 \text { - } 1.2 \mathrm{~m} \text { tall; avoided sparse vegetation and } \\
\text { dense grasses >1.2 m; preferred areas dominated by big } \\
\text { bluestem (Andropogon gerardii) and Indiangrass } \\
\text { (Sorghastrum nutans) }\end{array}$ \\
\hline Hanson 1994 & Minnesota & Idle native, idle tame & $\begin{array}{l}\text { Preferred areas with substantial uncompressed litter; } \\
\text { space between the bare ground and the bottom of the } \\
\text { litter layer, litter depth, overall litter cover, and height of } \\
\text { standing dead vegetation were all greater in areas of use } \\
\text { rather than areas of non-use; mean litter depth at used } \\
\text { areas was } 7.1 \mathrm{~cm} \text { and mean height of standing dead } \\
\text { vegetation was } 59.4 \mathrm{~cm}\end{array}$ \\
\hline Herkert 1994a,b & Illinois & $\begin{array}{l}\text { Burned tallgrass, } \\
\text { cropland, idle seeded- } \\
\text { native, idle tallgrass, } \\
\text { tame hayland }\end{array}$ & $\begin{array}{l}\text { Preferred large areas with taller, denser vegetation and a } \\
\text { higher proportion of residual standing dead plant } \\
\text { material; on grasslands } \geq 150 \text { ha, occupied areas had } \\
\text { significantly greater grass height and greater vegetation } \\
\text { height; vegetation at occupied sites was characterized by } \\
27.5 \mathrm{~cm} \text { mean grass height and } 47.2 \mathrm{~cm} \text { mean vegetation } \\
\text { height; were rarely encountered on grassland fragments }\end{array}$ \\
\hline
\end{tabular}




\begin{tabular}{|c|c|c|c|}
\hline & & & $<100$ ha \\
\hline Kahl et al. 1985 & Missouri & $\begin{array}{l}\text { Burned tallgrass, } \\
\text { cropland, idle, idle } \\
\text { tallgrass, tallgrass } \\
\text { hayland, tallgrass } \\
\text { pasture, woodland, } \\
\text { woodland edge }\end{array}$ & $\begin{array}{l}\text { Used song perches characterized by: no woody stems } \\
\geq 2.5 \mathrm{~cm} \text { diameter at breast height (dbh), few woody } \\
\text { stems }<2.5 \mathrm{~cm} \text { dbh (usually 0/ha, never }>100 / \mathrm{ha}) \text {, dense } \\
\text { ground vegetation of intermediate height }(20-40 \mathrm{~cm}) \text {, and } \\
\text { dense litter coverage }\end{array}$ \\
\hline Mazur 1996 & New York & Idle tame & $\begin{array}{l}\text { Inhabited large ( }>8 \text { ha), flat ( }<7 \% \text { slope) fields } \\
\text { dominated by knapweed (Centaurea spp.), brome grass } \\
\text { (Bromus spp.), and bedstraw (Galium spp.), with tall, } \\
\text { dense vegetation, a well established litter layer, and a } \\
\text { low density of woody-stemmed plants }\end{array}$ \\
\hline $\begin{array}{l}\text { Michaels 1997, Cully } \\
\text { and Michaels } 2000\end{array}$ & Kansas & $\begin{array}{l}\text { Burned tallgrass, idle } \\
\text { tallgrass, tallgrass } \\
\text { hayland }\end{array}$ & $\begin{array}{l}\text { Used areas characterized by low tree density, high } \\
\text { physiognomic cover diversity, deep litter, and high } \\
\text { coverage of litter; dense, homogenous vegetation; and } \\
\text { standing dead vegetation; used areas } 2-3 \text { growing } \\
\text { seasons postfire significantly more than } 0-1 \text { and }>4 \\
\text { growing seasons postfire; presence of some low, woody } \\
\text { vegetation did not reduce use of habitat }\end{array}$ \\
\hline Piehler 1987 & Pennsylvania & Idle tame & $\begin{array}{l}\text { Vegetation structure in territories was taller and denser } \\
\text { than in surrounding area; no territories contained shrub } \\
\text { cover; territories had } 98.0 \% \text { litter cover, } 2.0 \% \text { bare } \\
\text { ground, } 5.95 \mathrm{~cm} \text { litter depth, } 102.2 \mathrm{~cm} \text { mean vegetation } \\
\text { height, and } 117.3 \mathrm{~cm} \text { effective vegetation height }\end{array}$ \\
\hline $\begin{array}{l}\text { Reinking and } \\
\text { Hendricks } 1993\end{array}$ & Oklahoma & $\begin{array}{l}\text { Burned tallgrass, idle } \\
\text { tallgrass }\end{array}$ & Avoided nesting in spring-burned areas \\
\hline Robins 1971 & Michigan & Tame hayland & $\begin{array}{l}\text { Required an intermediate moisture range, dense } \\
\text { herbaceous vegetation, well-developed litter, and } \\
\text { available song perches }\end{array}$ \\
\hline
\end{tabular}




\begin{tabular}{|c|c|c|c|}
\hline $\begin{array}{l}\text { Rotenberry and Wiens } \\
1980\end{array}$ & $\begin{array}{l}\text { Colorado, Kansas, } \\
\text { Montana, Nebraska, } \\
\text { Oklahoma, Oregon, } \\
\text { South Dakota, } \\
\text { Texas, Washington, } \\
\text { Wisconsin, } \\
\text { Wyoming }\end{array}$ & $\begin{array}{l}\text { Idle mixed-grass, idle } \\
\text { shortgrass, idle } \\
\text { shrubsteppe, idle } \\
\text { tallgrass, montane } \\
\text { meadow }\end{array}$ & $\begin{array}{l}\text { Occurred only in tallgrass habitat; abundance was } \\
\text { correlated with percent litter cover }\end{array}$ \\
\hline Sample 1989 & Wisconsin & $\begin{array}{l}\text { Burned tallgrass, } \\
\text { cropland, DNC (idle } \\
\text { seeded-native, idle } \\
\text { tame), idle, idle } \\
\text { seeded-native, idle } \\
\text { tallgrass, idle } \\
\text { tallgrass/tame, idle } \\
\text { tame, tame hayland, } \\
\text { tame pasture, tame } \\
\text { savanna pasture, wet } \\
\text { meadow, wet-meadow } \\
\text { pasture }\end{array}$ & $\begin{array}{l}\text { Preferred mesic or wet habitats with relatively tall and } \\
\text { dense, but patchy, vegetation; were common in both } \\
\text { native and tame grasses; abundance was positively } \\
\text { correlated with percent cover of woody vegetation } 0-1 \mathrm{~m} \\
(0.79 \%) \text {, number of dead stems } 0-1 \mathrm{~m}\left(27.2 \mathrm{stems} / \mathrm{m}^{2}\right) \text {, } \\
\text { total number of dead stems }\left(110.8 \mathrm{stems} / \mathrm{m}^{2}\right) \text {, maximum } \\
\text { vegetation height ( } 88 \mathrm{~cm}) \text {, vegetation height/density ( } 40 \\
\mathrm{~cm}) \text {, and percent cover of standing residual vegetation } \\
(9.9 \%) \text {; abundance was negatively correlated with } \\
\text { percent cover of exposed soil }(1.0 \%)\end{array}$ \\
\hline Schulenberg et al. 1993 & Kansas & $\begin{array}{l}\text { Burned tallgrass, idle } \\
\text { tallgrass }\end{array}$ & $\begin{array}{l}\text { Singing males were located in unburned tallgrass but not } \\
\text { in burned tallgrass; one nest was found woven into dried } \\
\text { stems, } 10.2 \mathrm{~cm} \text { above ground; nest was well-concealed in } \\
\text { a } 37-39 \mathrm{~cm} \text { tall clump of little bluestem surrounded by } \\
\text { sedges (Carex spp.), forbs, and some free-standing } \\
\text { shrubs; nest site was characterized by } 10 \% \text { standing little } \\
\text { bluestem, } 10 \% \text { live little bluestem, } 25 \% \text { sedge, } 20 \% \\
\text { forbs (mostly blazing star [Liatris punctata] and Indian } \\
\text { hemp dogbane [Apocynum cannabinum]), } 5 \% \text { bare } \\
\text { ground, } 30 \% \text { litter, and }<2 \mathrm{~cm} \text { litter depth }\end{array}$ \\
\hline Skinner 1974 & Missouri & $\begin{array}{l}\text { Idle tallgrass, idle } \\
\text { tame, tallgrass }\end{array}$ & $\begin{array}{l}\text { Preferred idle grassland and grazed pastures with } \\
\text { vegetation height }>48 \mathrm{~cm} \text {; none were found in pasture }\end{array}$ \\
\hline
\end{tabular}




\begin{tabular}{|c|c|c|c|}
\hline & & $\begin{array}{l}\text { hayland, tallgrass } \\
\text { pasture, tame hayland, } \\
\text { tame pasture }\end{array}$ & $\begin{array}{l}<10 \mathrm{~cm} \text { or in hay stubble; avoided areas where forbs } \\
\text { predominate }\end{array}$ \\
\hline Skinner et al. 1984 & Missouri & $\begin{array}{l}\text { Burned tallgrass, idle } \\
\text { tallgrass, tallgrass } \\
\text { hayland, tallgrass } \\
\text { pasture, tame pasture }\end{array}$ & $\begin{array}{l}\text { Occupied areas with tall, dense cover; preferred lightly } \\
\text { grazed and idle grasslands; commonly occurred on } \\
\text { undisturbed grasslands even if they were disturbed the } \\
\text { previous year }\end{array}$ \\
\hline Smith and Smith 1992 & New York & Pasture & $\begin{array}{l}\text { Avoided pastures }<30 \text { ha; time since last mowing did not } \\
\text { influence late season (late July to early August) } \\
\text { distributions, several were found in areas mowed the } \\
\text { previous year }\end{array}$ \\
\hline Swengel 1996 & Missouri & $\begin{array}{l}\text { Burned tallgrass, } \\
\text { burned tallgrass } \\
\text { hayland, tallgrass } \\
\text { hayland, tallgrass } \\
\text { hayland/pasture }\end{array}$ & $\begin{array}{l}\text { Preferred large prairies } 1-2 \text { growing seasons after } \\
\text { conservation haying (one mowing after } 15 \text { July) or } \\
\text { burning }\end{array}$ \\
\hline Volkert 1992 & Wisconsin & $\begin{array}{l}\text { Burned tallgrass } \\
\text { (restored), idle } \\
\text { tallgrass (restored) }\end{array}$ & $\begin{array}{l}\text { Highest densities were observed 2-3 yr postburn; were } \\
\text { absent from recently burned prairie }\end{array}$ \\
\hline Wiens 1969 & Wisconsin & $\begin{array}{l}\text { Idle pasture, tame } \\
\text { pasture }\end{array}$ & $\begin{array}{l}\text { Occupied territories with greater mean litter depth, } \\
\text { effective vegetation height, and forb height than outside } \\
\text { of territories; occupied areas also had lower coverage } \\
\text { and density of forbs; territories had } 97 \% \text { grass cover, } \\
20 \% \text { forb cover, } 1 \% \text { bare ground, and } 5 \% \text { effective cover } \\
<5 \mathrm{~cm} \text {; of } 4 \text { territories, mean distance from territory } \\
\text { boundary to woods was } 175 \mathrm{~m} \text {, to fence line was } 22.5 \mathrm{~m} \text {, } \\
\text { and to cultivated field was } 40 \mathrm{~m} \text {; no territories contained } \\
\text { posts, fence lines, or trees }\end{array}$ \\
\hline Winter 1996; & Missouri & Idle tallgrass & Density was lower in small prairies and increased with \\
\hline
\end{tabular}




\begin{tabular}{|c|c|c|c|}
\hline $\begin{array}{l}\text { M. Winter, pers. } \\
\text { comm. }\end{array}$ & & & $\begin{array}{l}\text { increasing litter depth and decreasing bare soil cover; } \\
\text { nesting success did not differ with size of prairies }\end{array}$ \\
\hline Winter 1998, 1999 & Missouri & $\begin{array}{l}\text { Burned tallgrass, idle } \\
\text { tallgrass, tallgrass } \\
\text { hayland }\end{array}$ & $\begin{array}{l}\text { Placed nests among layers of thick litter about } 6-8 \mathrm{~cm} \\
\text { above the ground; most nests were covered by litter and } \\
\text { vegetation; nests were never placed near or within } \\
\text { woody habitat; mean vegetation measurements at } \\
\text { successful nest sites were } 3 \mathrm{~cm} \text { litter depth, } 43 \mathrm{~cm} \\
\text { vegetation height, } 0.25 \mathrm{~m} \text { visual obstruction, } 0.4 \text { woody } \\
\text { stems } / 0.15 \mathrm{~m}^{2}, 27 \% \text { litter cover, } 51 \% \text { grass cover, } 19 \% \\
\text { forb cover, } 2 \% \text { woody cover, and } 0.6 \% \text { bare soil }\end{array}$ \\
\hline Zimmerman 1988 & Kansas & $\begin{array}{l}\text { Burned tallgrass, idle } \\
\text { tallgrass }\end{array}$ & $\begin{array}{l}\text { Occupied territories characterized by greater coverage of } \\
\text { standing vegetation, lesser coverage of woody } \\
\text { vegetation, and taller live grasses than areas outside of } \\
\text { territories }\end{array}$ \\
\hline
\end{tabular}

*In an effort to standardize terminology among studies, various descriptors were used to denote the management or type of habitat. "Idle" used as a modifier (e.g., idle tallgrass) denotes undisturbed or unmanaged (e.g., not burned, mowed, or grazed) areas. "Idle" by itself denotes unmanaged areas in which the plant species were not mentioned. Examples of "idle" habitats include weedy or fallow areas (e.g., oldfields), fencerows, grassed waterways, terraces, ditches, and road rights-of-way. "Tame" denotes introduced plant species (e.g., smooth brome [Bromus inermis]) that are not native to North American prairies. "Hayland" refers to any habitat that was mowed, regardless of whether the resulting cut vegetation was removed. "Burned" includes habitats that were burned intentionally or accidentally or those burned by natural forces (e.g., lightning). In situations where there are two or more descriptors (e.g., idle tame hayland), the first descriptor modifies the following descriptors. For example, idle tame hayland is habitat that is usually mowed annually but happened to be undisturbed during the year of the study. 


\section{LITERATURE CITED}

Birkenholz, D. E. 1973. Habitat relationships of grassland birds at Goose Lake Prairie Nature Preserve. Pages 63-66 in L. C. Hulbert, editor. Proceedings of the Third Midwest Prairie Conference. Kansas State University, Manhattan, Kansas.

Bollinger, E. K. 1991. Conservation of grassland birds in agricultural areas. Pages 279-287 in D. J. Decker, M. E. Krasny, G. R. Goff, C. R. Smith, and D. W. Gross, editors. Challenges in the conservation of biological resources. Westview Press, Boulder, Colorado.

Bollinger, E. K. 1995. The effects of habitat selection and vegetation succession on the breeding dispersion of birds nesting in eastern hayfields. Auk 112:720-730.

Clawson, R. L. 1991. Henslow's Sparrow habitat, site fidelity, and reproduction in Missouri. Final Report. Federal Aid Project Number W-13-R-45, Study Number 18, Job Number 1. Missouri Department of Conservation, Jefferson City, Missouri. 16 pages.

Cully, J. F., Jr., and H. L. Michaels. 2000. Henslow's Sparrow habitat associations on Kansas tallgrass prairie. Wilson Bulletin 112:115-123.

Eddleman, W. R. 1974. The effects of burning and grazing on bird populations in native prairie in the Kansas Flint Hills. Unpublished report, National Science FoundationUndergraduate Research Program. Kansas State University, Manhattan, Kansas. 33 pages.

Friedmann, H., and L. F. Kiff. 1985. The parasitic cowbirds and their hosts. Proceedings of the Western Foundation of Vertebrate Zoology 2:226-304.

George, J. L. 1952. The birds on a southern Michigan farm. Ph.D. thesis. University of Michigan, Ann Arbor, Michigan. 416 pages.

Graber, J. W. 1968. Western Henslow’s Sparrow. Pages 776-777 in A. C. Bent, editor. Life histories of North American cardinals, grosbeaks, buntings, towhees, finches, sparrows, and allies, Part 2. Dover Publications, New York, New York.

Hands, H. M., R. D. Drobney, and M. R. Ryan. 1989. Status of the Henslow's Sparrow in the northcentral United States. U.S. Fish and Wildlife Service Report, Missouri Cooperative Fish and Wildlife Research Unit, University of Missouri, Columbia, Missouri. 12 pages.

Hanson, L. G. 1994. The Henslow's Sparrow (Ammodramus henslowii) of Minnesota: population status and breeding habitat analysis. M.S. thesis. Central Michigan University, Mount Pleasant, Michigan. 29 pages.

Hayden, T. J. 1985. Minimum area requirements of some breeding bird species in fragmented habitats in Missouri. M.A. thesis. University of Missouri, Columbia, Missouri. 148 pages.

Helzer, C. J. 1996. The effects of wet meadow fragmentation on grassland birds. M.S. thesis. University of Nebraska, Lincoln, Nebraska. 65 pages. 
Helzer, C. J., and D. E. Jelinski. 1999. The relative importance of patch area and perimeter-area ratio to grassland breeding birds. Ecological Applications 9:1448-1458.

Herkert, J. R. 1991. An ecological study of the breeding birds of grassland habitats within Illinois. Ph.D. dissertation. University of Illinois, Urbana, Illinois. 112 pages.

Herkert, J. R. 1994a. Status and habitat selection of the Henslow’s Sparrow. Wilson Bulletin 106:35-45.

Herkert, J. R. 1994b. The effects of habitat fragmentation on midwestern grassland bird communities. Ecological Applications 4:461-471.

Herkert, J. R., and W. D. Glass. 1999. Henslow's Sparrow response to prescribed fire in an Illinois prairie remnant. Pages 160-164 in P. D. Vickery and J. R. Herkert, editors. Ecology and conservation of grassland birds of the Western Hemisphere. Studies in Avian Biology 19.

Herkert, J. R., R. E. Szafoni, V. M. Kleen, and J. E. Schwegman. 1993. Habitat establishment, enhancement and management for forest and grassland birds in Illinois. Illinois Department of Conservation, Division of Natural Heritage, Natural Heritage Technical Publication 1, Springfield, Illinois. 20 pages.

Kahl, R. B., T. S. Baskett, J. A. Ellis, and J. N. Burroughs. 1985. Characteristics of summer habitats of selected nongame birds in Missouri. Research Bulletin 1056. University of Missouri-Columbia, Columbia, Missouri. 155 pages.

Koford, R. R. 1997. Status of Henslow's Sparrow in the former tall-grass prairie ecosystem. Progress report submitted to the Biological Resources Division, U.S. Geological Survey and Region 3, U.S. Fish and Wildlife Service. 52+ pages.

Mazur, R. 1996. Implication of field management for Henslow’s Sparrow habitat at Saratoga National Historic Park, New York. M.S. thesis. University of New York, Syracuse, New York. 33 pages.

Melde, P. B., and R. R. Koford. 1996. Henslow’s Sparrow nesting observations, habitat associations and history in Iowa. Iowa Bird Life 66:117-122.

Michaels, H. L. 1997. Landscape and fine scale habitat associations of the Loggerhead Shrike and Henslow's Sparrow on Fort Riley Military Installation, Kansas. M.S. thesis. Kansas State University. 109 pages.

National Geographic Society. 1987. Field guide to the birds of North America, second edition. National Geographic Society, Washington, D.C. 464 pages.

O’Leary, C. H., and D. W. Nyberg. 2000. Treelines between fields reduce the density of grassland birds. Natural Areas Journal 20:243-249.

Peck, G. K., and R. D. James. 1987. Breeding birds of Ontario, volume 2: passerines. Royal Ontario Museum Publications in Life Sciences. Royal Ontario Museum, Toronto, Ontario. 387 pages. 
Peterson, A. 1983. Observations on habitat selection by Henslow's Sparrow in Broome County, New York. Kingbird 33:155-164.

Piehler, K. G. 1987. Habitat relationships of three grassland sparrow species on reclaimed surface mines in Pennsylvania. M.S. thesis. West Virginia University, Morgantown, West Virginia. 78 pages.

Potter, L. H. 1915. Short-billed Marsh Wren and Henslow’s Sparrow at Clarendon. Vermont Botany and Bird Clubs Joint Bulletin 1:19-20.

Pruitt, L. 1996. Henslow's Sparrow status assessment. United States Fish and Wildlife Services, Bloomington, Indiana. 113 pages.

Reinking, D. L., D. A. Wiedenfeld, D. H. Wolfe, and R. W. Rohrbaugh, Jr. 2000. Distribution, habitat use, and nesting success of Henslow's Sparrow in Oklahoma. Prairie Naturalist 32:219-232.

Reinking, D. L., and D. P. Hendricks. 1993. Occurrence and nesting of Henslow's Sparrow in Oklahoma. Bulletin of the Oklahoma Ornithological Society 26:33-36.

Robins, J. D. 1971. A study of the Henslow’s Sparrow in Michigan. Wilson Bulletin 83:29-48.

Rotenberry, J. T., and J. A. Wiens. 1980. Habitat structure, patchiness, and avian communities in North American steppe vegetation: a multivariate analysis. Ecology 61:1228-1250.

Sample, D. W. 1989. Grassland birds in southern Wisconsin: habitat preference, population trends, and response to land use changes. M.S. thesis. University of Wisconsin, Madison, Wisconsin. 588 pages.

Schulenberg, J. H., G. L. Horak, M. D. Schwilling, and E. J. Finck. 1994. Nesitng of Henslow's Sparrow in Osage County, Kansas. Kansas Ornithological Society Bulletin 45:25-28.

Skinner, R. M. 1974. Grassland use patterns and prairie bird populations in Missouri. M.A. thesis. University of Missouri, Columbia, Missouri. 53 pages.

Skinner, R. M. 1975. Grassland use patterns and prairie bird populations in Missouri. Pages 171-180 in M. K. Wali, editor. Prairie: a multiple view. University of North Dakota Press, Grand Forks, North Dakota.

Skinner, R. M. 1982. Vegetation structure and bird habitat selection on Missouri prairies. Ph.D. dissertation. University of Missouri, Columbia, Missouri. 108 pages.

Skinner, R. M., T. S. Baskett, and M. D. Blendon. 1984. Bird habitat on Missouri prairies. Terrestrial Series 14. Missouri Department of Conservation, Jefferson City, Missouri. 37 pages.

Skipper, C. S. 1998. Henslow's Sparrows return to previous nest site in western Maryland. North American Bird Bander 23:36-41. 
Smith, C. R. 1992. Henslow’s Sparrow, Ammodramus henslowii. Pages 315-330 in K. J. Schneider and D. M. Pence, editors. Migratory nongame birds of management concern in the Northeast. U.S. Fish and Wildlife Service, Newton Corner, Massachusetts.

Smith, D. J., and C. R. Smith. 1992. Henslow’s Sparrow and Grasshopper Sparrow: a comparison of habitat use in Finger Lakes National Forest, New York. Bird Observer 20:187-194.

Swengel, S. R. 1996. Management responses of three species of declining sparrows in tallgrass prairie. Bird Conservation International 6:241-253.

Temple, S. A., B. M. Fevold, L. K. Paine, D. J. Undersander, and D. W. Sample. 1999. Nesting birds and grazing cattle: accommodating both on midwestern pastures. Pages 196-202 in P. D. Vickery and J. R. Herkert, editors. Ecology and conservation of grassland birds of the Western Hemisphere. Studies in Avian Biology 19.

Volkert, W. K. 1992. Response of grassland birds to a large-scale prairie planting project. Passenger Pigeon 54:190-196.

Wiens, J. A. 1969. An approach to the study of ecological relationships among grassland birds. Ornithological Monographs 8:1-93.

Winter, M. 1996. How does fragmentation affect grassland birds in southwestern Missouri prairies? Missouri Prairie Journal 17:15-18.

Winter, M. 1998. Effect of habitat fragmentation on grassland-nesting birds in southwestern Missouri. Ph.D. dissertation. University of Missouri, Columbia, Missouri. 215 pages.

Winter, M. 1999. Nesting biology of Dickcissels and Henslow's Sparrows in Missouri prairie fragments. Wilson Bulletin 111:515-527.

Winter, M., and J. Faaborg. 1999. Patterns of area sensitivity in grassland-nesting birds. Conservation Biology 13:1424-1436.

Winter, M., D. H. Johnson, and J. Faaborg. 2000. Evidence for edge effects on multiple levels in tallgrass prairie. Condor 102:256-266.

Zimmerman, J. L. 1997. Avian community responses to fire, grazing, and drought in the tallgrass prairie. Pages 167-180 in F. L. Knopf and F. B. Samson, editors. Ecology and conservation of Great Plains vertebrates. Springer-Verlag, New York, New York.

Zimmerman, J. L. 1988. Breeding season habitat selection by the Henslow's Sparrow (Ammodramus henslowii) in Kansas. Wilson Bulletin 100:17-24.

Zimmerman, J. L., and E. J. Finck. 1983. Success in a secondary habitat: the Dickcissel in the tallgrass prairie. Pages 47-49 in R. Brewer, editor. Proceedings of the eighth North American Prairie Conference. Western Michigan University, Kalamazoo, Michigan. 